BACKGROUND: Tumor necrosis factor (TNF)- $\alpha$ and interleukin (IL)-1 $\beta$ are pro-inflammatory cytokines, causing myocardial dysfunction and a negative inotropic effect. The drugs used to treat heart failure affect the production of cytokines. Digoxin, on which this study was focused, is one of the drugs for the treatment of heart failure.

Aim: The present study was designed to examine the early effects of high doses of digoxin on the production of cytokines in healthy dogs.

Methods: Digoxin was given parenterally to dogs at $0.15 \mathrm{mg} / \mathrm{kg}$. IL-1 $\beta$ and TNF- $\alpha$ production and levels of digoxin in the serum were measured $0,12,24,48$, and $72 \mathrm{~h}$ following administration of digoxin.

Results: As the levels of serum digoxin taken at 12, 24, 48 , and $72 \mathrm{~h}$ of administration were considered significantly high compared with preceding values $(p$ $<0.001$ ), no notable change in serum IL-1 $\beta$ and TNF- $\alpha$ levels was observed.

Conclusions: These results suggest that high doses of digoxin do not cause a significant cytokine production in heart muscle in the early phase.

Key words: High dose, Digoxin, Cytokines

\section{The effect of high dose digoxin on cytokines in healthy dogs}

\author{
Haluk Dülger',CA , Mehmet Ramazan Şekeroğlu², \\ Beyhan Eryonucu $^{2}$, Tevfik Noyan ${ }^{1}$ and \\ Süleyman Alici ${ }^{3}$
}

${ }^{1}$ Department of Biochemistry, ${ }^{2}$ Department of Cardiology, and ${ }^{3}$ Department of Internal Medicine, School of Medicine, University of Yüzüncü Yil, Yüzüncü Yil Üniversitesi, Tip Fakültesi, Biyokimya Anabilim Dali, Maraş Caddesi, 65300 Van, Turkey

\author{
${ }^{\mathrm{CA}}$ Corresponding Author \\ Tel/fax: +90 4322167462 \\ E-mail: halukdulger@yahoo.com
}

\section{Introduction}

Tumor necrosis factor (TNF)- $\alpha$ and interleukin (IL)-1 $\beta$ are pro-inflammatory cytokines, causing myocardial dysfunction and a negative inotropic effect. The drugs used to treat heart failure affect the production of cytokines. Digoxin, on which this study was focused, is one of the drugs for the treatment of heart failure. ${ }^{1,2}$ Tumor necrosis factor (cachectin) is a pluripotent cytokine, produced primarily by monocytes, that has been shown experimentally to cause fever and hypotension. Elevated circulating levels of TNF have been noted in patients with a variety of neoplastic, infectious, and collagen vascular disorders, many of which are characterized by severe weight loss and anorexia. $^{3}$

In normal doses, digoxin has a positive effect on heart function via inhibition of sodium/potassium ATPase or indirectly via the sympathicus nerve and kidneys. Digoxin is one of the most commonly prescribed drugs for the treatment of heart failure, and efficacy of digoxin in patients with heart failure and atrial fibrillation is clear. However, this efficacy in patients with heart failure and sinus rhythm has not established. Digoxin has no significant effect on mortality. Several recent short-term, randomized trials indicated that withdrawing digoxin worsens functional status, exercise capacity, and the left ventricular ejection fraction in patients with heart failure, but there is uncertainty about its efficacy and safety. 4,5
We hypothesized that negative effects by high doses of digoxin could be achieved by the release of cytokines. This study was designed to examine the early effects of high doses of digoxin on the production of cytokines in healthy dogs.

\section{Materials and methods}

Healthy dogs were used for the present study. Ten dogs were included in the study. The study was approved by an internal ethical review board. Digoxin was given parenterally at $0.15 \mathrm{mg} / \mathrm{kg}$, which is fivefold higher than the usual therapeutic dose. It is difficult to compare dosages in different animal species; however, on the basis of the body surface area, a given dosage in dogs is comparable with a dosage about four-fold lower in humans. Thus, a dosage of $0.03 \mathrm{mg} / \mathrm{kg}$ of digoxin in dogs is equivalent to $0.008 \mathrm{mg} / \mathrm{kg}$ in humans, which is a therapeutic dose. $^{2}$ None of these dogs died. A total of $5 \mathrm{ml}$ of venous blood was drawn from each dog at 12, 24, 48, and $72 \mathrm{~h}$ following administration of digoxin. Blood samples were was then centrifuged at $2000 \mathrm{rpm}$ for $10 \mathrm{~min}$ in a refrigerated centrifuge to separate serum samples from the cells. Serum samples were stored at $-70^{\circ} \mathrm{C}$ in plastic tubes until the analysis. IL- $1 \beta$ and TNF- $_{\alpha}$ production and levels of digoxin in the serum samples were measured.

Serum digoxin, IL-1 $\beta$ and TNF- $\alpha$ was measured using commercial kits, which are a solid-phase, two-site 
Table 1. The values of digoxin, IL-1 $\beta$ and TNF- $\alpha$ obtained before and after administration of digoxin

\begin{tabular}{|c|c|c|c|c|c|}
\hline & $\mathrm{Oh}$ (control) & $12 \mathrm{~h}$ & $24 \mathrm{~h}$ & $48 \mathrm{~h}$ & $72 \mathrm{~h}$ \\
\hline $\begin{array}{l}\text { Digoxin (ng/ml) } \\
\mathrm{IL}-1_{\beta}(\mathrm{pg} / \mathrm{ml}) \\
\operatorname{TNF}_{-\alpha}(\mathrm{pg} / \mathrm{ml})\end{array}$ & $\begin{array}{l}0.8 \pm 0.14 \\
0.9 \pm 0.35 \\
3.4 \pm 0.64\end{array}$ & $\begin{array}{c}12.0 \pm 1.29 * \\
1.1 \pm 0.11 \\
4.0 \pm 0.50\end{array}$ & $\begin{array}{l}7.8 \pm 0.53^{*} \\
0.9 \pm 0.13 \\
3.1 \pm 0.45\end{array}$ & $\begin{array}{l}3.7 \pm 0.22^{*} \\
0.9 \pm 0.19 \\
3.2 \pm 0.44\end{array}$ & $\begin{array}{l}3.0 \pm 0.31^{*} \\
0.4 \pm 0.10 \\
3.3 \pm 0.47\end{array}$ \\
\hline
\end{tabular}

$* p<0.001$.

chemiluminescent immunometric assay (Immullite; DPC, Los Angeles, USA). Performance data for digoxin, IL- $1 \beta$ and TNF- $\alpha$, respectively, are as follows: calibration ranges, $0.5-8 \mathrm{ng} / \mathrm{ml}$, up to $1000 \mathrm{pg} / \mathrm{ml}$, and up to $1000 \mathrm{pg} / \mathrm{ml}$; analytical sensitivities, $0.1 \mathrm{ng} / \mathrm{ml}, 1.5 \mathrm{pg} /$ $\mathrm{ml}$, and $1.7 \mathrm{pg} / \mathrm{ml}$; intra-assay coefficients of variation, $4.4 \%$ at a concentration of $1.6 \mathrm{ng} / \mathrm{ml}, 2.8 \%$ at a concentration of $39 \mathrm{pg} / \mathrm{ml}$, and $3.5 \%$ at a concentration of $34 \mathrm{pg} / \mathrm{ml}$; inter-assay coefficients of variation, $9.4 \%$ at a concentration of $1.6 \mathrm{ng} / \mathrm{ml}, 7.7 \%$ at a concentration of $13 \mathrm{pg} / \mathrm{ml}$, and $6.5 \%$ at a concentration of $17 \mathrm{pg} /$ $\mathrm{ml}$; linearities, $94 \%$ at a dilution of 2 in $5,95 \%$ at a dilution of 4 in 8 , and $90 \%$ at a dilution of 4 in 8 ; and recoveries, average $109 \%, 102 \%$, and $99 \%$.

The obtained data were analyzed by Wilcoxon's rank sum tests.

\section{Results}

Digoxin, IL-1 $\beta$ and TNF- $\alpha$ values obtained before and at $12,24,48$, and $72 \mathrm{~h}$ following the administration of digoxin are presented in Table 1 .

As the levels of serum digoxin observed at 12, 24, 48 , and $72 \mathrm{~h}$ of administration were considered significantly high compared with preceding values $(p$ $<0.001$ ), no notable change in serum IL-1 $\beta$ and TNF- $\alpha$ levels was observed.

\section{Discussion}

In previous studies, it was reported that $\mathrm{IL}^{-1} \beta$ and $\mathrm{TNF}_{-} \alpha$ levels were increased in patients with heart failure. In the present study, we planned to investigate the effect of high dose digoxin on IL- $1 \beta$ and TNF- $\alpha$ levels in healthy subjects without any previous heart failure, thereby using healthy dogs.

Each cytokine that shows various features is synthesized by special cell types to be a response to a specific stimulus. TNF and IL-1 are mediators of natural immunity and they are synthesized by mononuclear phagocytes. ${ }^{6}$

Cytokines are now being considered important factors in the pathogenesis and pathophysiology of heart failure. High levels of circulating cytokines have been reported in patients with heart failure, and various cytokines have been shown to depress myocardial contractility in vitro and in vivo. ${ }^{1,7}$ Although the effect of IL-1 on cardiac function remains controversial, it has been shown to decrease cardiac contractility. ${ }^{8}$ More recently, IL- $1 \beta$ has been found to cause myocyte hypertrophy associated with the induction of fetal genes. ${ }^{9}$ Another recent study has reported that the chronic infusion of $\mathrm{TNF}_{-} \alpha$ in rats produces left ventricular contractile dysfunction and dilatation. ${ }^{10}$ Transgenic overexpression of $\mathrm{TNF}_{-} \alpha$ in the heart, using the cardiac-specific $\alpha$-myosin heavy chain promoter, has just been reported to cause systolic dysfunction, myocarditis, ventricular dilatation, and the development of heart failure. ${ }^{11}$ Furthermore, another transgenic line expressing lower levels of cardiacTNF- $\alpha$ caused dilated cardiomyopathy without prominent inflammation. ${ }^{12}$ Thus, available data pertaining to cardiac transgenic overexpression of TNF- $\alpha$ point to a direct relation between cytokine concentrations and inflammatory response or mortality. ${ }^{13} \mathrm{TNF}_{-\alpha}$ is a pro-inflammatory cytokine that produces left ventricular dysfunction and a negative inotropic effect in cardiac tissue when it is overexpressed in human subjects. Previous studies have shown that levels of circulating TNF- $\alpha$ are elevated in patients with advanced congestive heart failure, and especially in those with cardiac cachexia. ${ }^{14}$

In the present study, in the result of administration of a five-fold higher dose of digoxin, no increase in IL$1 \beta$ and $\mathrm{TNF}_{\alpha} \alpha$ levels was observed within $72 \mathrm{~h}$. Matsumori et $a .^{2}$ showed that digoxin increased the levels of cytokines IL- $1 \beta$, IL- 6 and TNF- $\alpha$ in cardiac muscle of mice with viral myocarditis. But it is not certain that this increase was solely due to digoxin other than myocarditis and cardiac heart failure.

In another study conducted by Matsumori et al., ${ }^{15}$ they found that the cardiac glycoside ouabain induces the production of IL- $1 \beta$, IL- 6 and TNF- $\alpha$ in human peripheral blood mononuclear cells. Ouabain induced mRNA of these cytokines, and the induction appeared to be at the transcriptional level. When peripheral blood mononuclear cells were stimulated with lipopolysaccharide, however, ouabain suppressed the production of IL- 6 and TNF- $\alpha$. Thus, cardiac glycosides may be considered to have different effects on the production of cytokines among those with and those without immune activation. ${ }^{2}$

There may be various reasons for not observing any notable changes in IL-1 $\beta$ and TNF- $\alpha$ levels in our study when used high doses of digoxin. First, we used five times as much digoxin as a normal therapeutic dose. 
This may have caused us to not observe any notable results in the present study, but we think that if much higher doses of digoxin had been used in this study, much more notable results would have been observed. Second, the present study was performed only on healthy dogs. The effect of digoxin may of course be different both in healthy dogs and in dogs with heart failure. In fact, Matsumori et al. ${ }^{2}$ showed that high doses of digoxin increased the serum IL-1 $\beta$ and TNF- $\alpha$ levels in mice with heart failure developed by viral myocarditis.

In the present study, serum $\mathrm{TNF} \alpha$ and IL- $1 \beta$ levels were no different from those of the controls. These results may suggest that high-dose digoxin might not causes a significant cytokine production in early phase. But our results need to be supported with further studies with longer or different doses of digoxin treatment.

ACKNOWLEDGEMENTS. The authors are extremely thankful to Ayten Babacan, B.A., the lecturer for Medical English at the School of Medicine, University of Yüzüncü Yil, for her correction in the redaction of this paper.

\section{References}

1. Levine B, Kalman J, Mayer L, Fillit HM, Packer M. Elevated circulating levels of tumour necrosis factor in severe chronic heart failure. $N$ Engl J Med 1990; 323: 236-241.

2. Matsumori A, Igata H, Ono K, Iwasaki A, Miyamoto T, Nishio R, Sasayama S. High doses of digitalis increase the myocardial production of proinflammatory cytokines and worsen myocardial injury in viral myocarditis: a possible mechanism of digitalis toxicity. Jpn Circ J 1999; 63: $934-940$.

3. Giradin E, Grav GE, Dayer JM, Roux-Lombard P, J5 Study Group, Lambert $\mathrm{PH}$. Tumour necrosis factor and interleukin-1 in the serum of children with severe infectious purpura. N Engl J Med 1998; 319: 397-400.
4. The Digitalis Investigation Group. The effect of digoxin on mortality and morbidity in patients with heart failure. N Engl J Med 1997; 336: $525-533$.

5. Uretsky BF, Young JB, Shahidi FE, Yellen LG, Harrison MC, Jolly MK. Randomized study assessing the effect of digoxin withdrawal in patients with mild to moderate chronic congestive heart failure; results of the PROVED Trial. J Am Coll Cardiol 1993; 22: 955-962.

6. Abbas Abul K. Cellular and Moleculer Immunology, 2nd edn. Pennsylvania: WB. Saunders Company, 1994; 239-260.

7. Yokoyama T, Vaca L, Rossen RD, Durante W, Hazarika P, Mann DL. Cellular basis for the negative inotropic effects of tumor necrosis factor- $\alpha$ in the adult mammalian heart. J Clin Invest 1993; 92: 2303-2312.

8. Evans HG, Lewis MJ, Shah AM. Interleukin- $1_{\beta}$ modulates myocardial contraction via dexamethasone-sensitive production of nitric oxide. Cardiovasc Res 1993; 27: 1486-1490.

9. Thaik CM, Calderone A, Takahashi N, Colucci S. Interleukin- $1 \beta$ modulates the growth and phenotype of neonatal rat cardiac myocytes.J Clin Invest 1995; 96: 1093-1099.

10. Bozkurt B, Kribbs SB, Clubb FJ Jr, Michael LH, Didenko VV, Homsby PJ, et al. Pathophysiologically relevant concentrations of tumor necrosis factor $^{-} \alpha$ promote progressive left ventricular dysfunction and remodeling in rats. Circulation 1998; 97: 1382-1391.

11. Bryant D, Becker L, Richardson J, Shelton J, Franco F, Peshock R, et al. Cardiac failure in transgenic mice with myocardial expression of tumor necrosis factor- $\alpha$. Circulation 1998; 97: 1375-1381.

12. Kubota T, McTiernan CF, Frye CS, Slawson SE, Lemster BH, Koretsky AP, et al. Dilated cardiomyopathy in transgenic mice with cardiac-specific overexpression of tumor necrosis factor- $\alpha$. Circ Res 1997; 81: 627-635.

13. Bristow MR. Tumor necrosis factor- $\alpha$ and cardiomyopathy. Circulation 1998; 97: 1340-1342.

14. Parissis JT, Venetsanou KF, Mentzikof DG, Ziras NG, Kefalas CG, Karas SM. Tumor necrosis factor-alpha serum activity during treatment of acute decompensation of cachectic and non-cachectic patients with advanced congestive heart failure. Scand Cardiovasc J 1999; 33: 344-350.

15. Matsumori $\mathrm{A}$, Ono $\mathrm{K}$, Nishio $\mathrm{R}$, Igata $\mathrm{H}$, Shioi $\mathrm{T}$, Matsui $\mathrm{S}$, et al. Modulation of cytokine production and protection against lethal endotoxemia by the cardiac glycoside oubain. Circulation 1997; 96 1501-1506.

Received 10 January 2002

Accepted 22 April 2002 


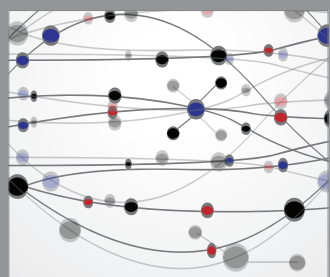

The Scientific World Journal
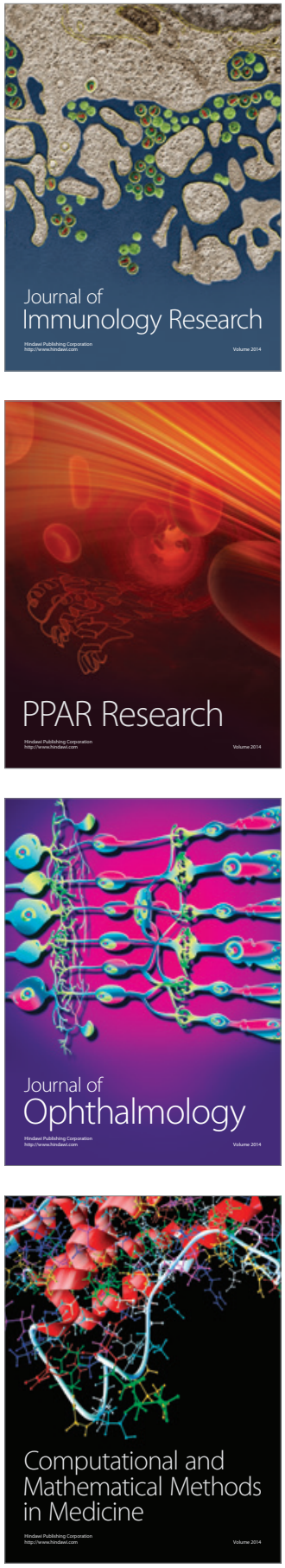

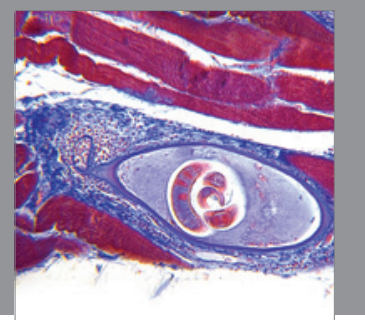

Gastroenterology

Research and Practice
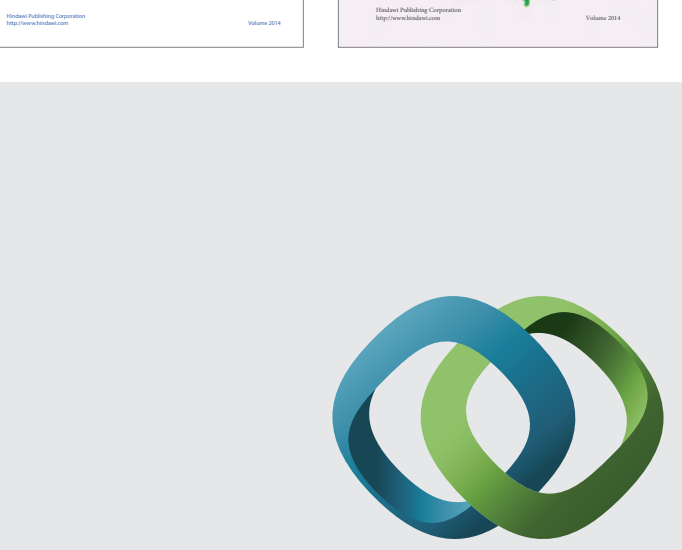

\section{Hindawi}

Submit your manuscripts at

http://www.hindawi.com
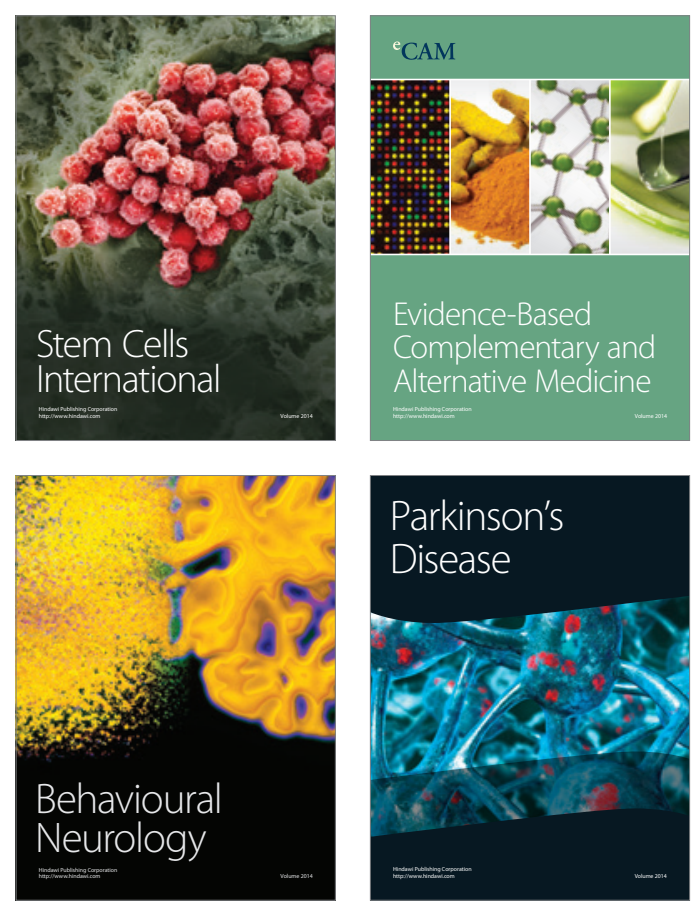

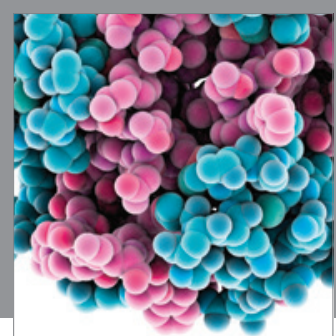

Journal of
Diabetes Research

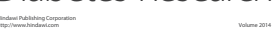

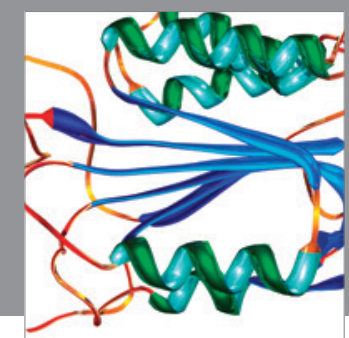

Disease Markers
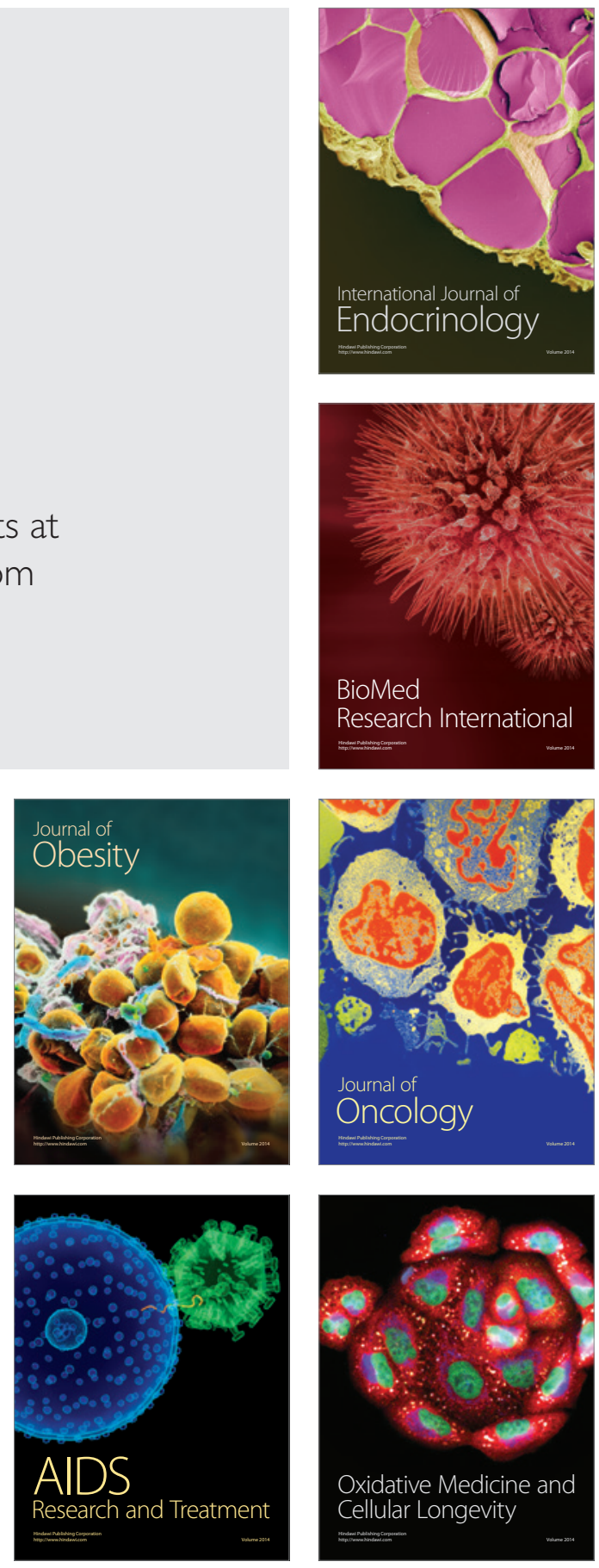